\title{
Statins decrease mortality in Lebanese patients with sepsis: A multicenter study
}

\author{
Rola AJROUCHE, Amal AL-HAJJE, Nancy EL-HELOU, Sanaa AWADA, Samar RACHIDI, \\ Salam ZEIN, Pascale SALAMEH \\ Received (first version): 11-Jan-2013 Accepted: 9-May-2013
}

\begin{abstract}
${ }^{*}$
Background: Sepsis is a significant public health concern. The clinical response to statins is variable among sepsis patients.

Objective: The aim of the study was to determinate the effect of statin-treatment on mortality in

Lebanese patients with sepsis.

Methods: A retrospective multicenter study on Lebanese patients with sepsis between January 2008 and March 2012 was conducted. Patients with a primary diagnosis of sepsis admitted to the intensive care unit of two tertiary care hospitals in Beirut were included. Patients who continued to receive statin therapy for dyslipidemia during the hospital course were included in the statin treatment group. The control group consisted of patients not taking statin. Demographic characteristics, clinical signs, standard laboratory test and treatment received were compared between these two groups using univariate analysis. Logistic regression and survival analysis were performed by SPSS.

Results: Three hundred fifty one Lebanese patients were included (age: $71.33 \mathrm{SD}=14.97$ years; Male: $56 \%$ ). Among them, $30 \%$ took a statin at the doses recommended for dyslipidemia. The comparison of the two groups showed that in the statin treatment group: The mean serum level of C-reactive protein at the time of sepsis was significantly decreased $(P=0.050)$, the length-stay at ICU significantly increased $(P=0.047)$ and mortality significantly
\end{abstract}

\footnotetext{
Rola AJROUCHE.PharmD. Clinical and Epidemiological Research Laboratory, Faculty of Pharmacy \& Clinical Pharmacy department, Doctoral School of Sciences \& Technology. Lebanese University. Beirut (Lebanon). Amal AL-HAJJE. PhD. Clinical and Epidemiological Research Laboratory, Faculty of Pharmacy \& Clinical Pharmacy department, Doctoral School of Sciences \& Technology. Lebanese University. Beirut (Lebanon). Nancy EL-HELOU. PharmD. Clinical and Epidemiological Research Laboratory, Faculty of Pharmacy \& Clinical Pharmacy department, Doctoral School of Sciences \& Technology. Lebanese University. Beirut (Lebanon). Sanaa AWADA. PhD. Clinical and Epidemiological Research Laboratory, Faculty of Pharmacy \& Clinical Pharmacy department, Doctoral School of Sciences \& Technology. Lebanese University. Beirut (Lebanon). Samar RACHIDI. PhD. Clinical and Epidemiological Research Laboratory, Faculty of Pharmacy \& Clinical Pharmacy department, Doctoral School of Sciences \& Technology. Lebanese University. Beirut (Lebanon). Salam ZEIN. DIS. Clinical and Epidemiological Research Laboratory, Faculty of Pharmacy \& Clinical Pharmacy department, Doctoral School of Sciences \& Technology. Lebanese University. Beirut (Lebanon).

Pascale SALAMEH. PhD. Clinical and Epidemiological Research Laboratory, Faculty of Pharmacy \& Clinical Pharmacy department, Doctoral School of Sciences \& Technology. Lebanese University. Beirut (Lebanon).
}

reduced $(P<0.001)$. Results were confirmed by logistic regression, particularly for mortality. In the Cox regression analysis, hypothermia and shock were significantly associated with high mortality while statin treatment decreased mortality (hazard ratio $=0.540 ; 95 \% \mathrm{Cl}: 0.302-0.964 ; \mathrm{P}=0.037$ ). Conclusion: At usual doses for dyslipidemia, statin treatment decreased incidence of mortality related to sepsis and improved the survival in this Lebanese septic population. Large randomized controlled clinical trials must be realized to give conclusive results about the potential beneficial effect of statins in sepsis.

Keywords: Sepsis; Hydroxymethylglutaryl-CoA Reductase Inhibitors; Mortality; Survival Analysis; Lebanon

\section{LAS ESTATINAS DISMINUYEN LA MORTALIDAD EN PACIENTES LIBANESES CON SEPSIS: ESTUDIO MULTICÉNTRICO}

\section{RESUMEN}

Antecedentes: La sepsis es un significativo problema de salud pública. La respuesta clínica a las estatinas es variable entre los pacientes con sepsis.

Objetivo: El objetivo del estudio fue determinar el efecto del tratamiento con estatinas en la mortalidad de pacientes libaneses con sepsis. Métodos: Se realizó un estudio multicentrico retrospectivo en pacientes libaneses con sepsis entre enero 2008 y marzo 2012. Se incluyeron los pacientes con un diagnóstico primario de sepsis ingresados en la unidad de cuidados intensivos de dos hospitales de Beirut. Se incluyó en el grupo de tratamiento a los pacientes que continuaron recibiendo estatinas para dislipidemia durante la estancia hospitalaria. El grupo control consistió en pacientes que no tomaron estatinas. Utilizando análisis univariado, se compararon entre estos dos grupos las características demográficas, signos clínicos, resultados de laboratorio y tratamiento recibido. Se realizó una regresión logística y un análisis de supervivencia con un SPSS.

Resultados: Se incluyó a 351 pacientes libaneses (edad 71,33 DE=14,97 años; 56\% hombres). Entre ellos, el 30\% tomaba estatinas a dosis recomendadas para dislipemia. La comparación de los dos grupos mostró que en el grupo de tratamiento con estatinas: el nivel sérico medio de proteína C-reactiva estaba significativamente disminuido $(p=0,050)$, la estancia en UCI significativamente aumentada $(\mathrm{p}=0,047)$ y la mortalidad significativamente reducida $(\mathrm{p}<0,001)$. Los resultados se confirmaron con una regresión 
logística, particularmente para la mortalidad. En el análisis de regresión de Cox, la hipotermia y el shock estaban significativamente asociados a alta mortalidad, mientras que el tratamiento con estatinas disminuyó la mortalidad (hazard ratio $=$ 0.540; 95\% CI: 0.302-0.964; $\mathrm{P}=0.037$ ).

Conclusión: A dosis habituales para dislipemia, el tratamiento con estatinas disminuyó la mortalidad relacionada con la sepsis y mejoró la supervivencia en una población séptica libanesa. Deben realizarse ensayos controlados aleatorizados grandes para proporcionar resultados conclusivos sobre el potencial efecto benéfico de las estatinas en la sepsis.

Palabras clave: Sepsis; Inhibidores de Hidroximetilglutaril-CoA Reductasas; Mortalidad; Análisis de Supervivencia; Líbano

\section{INTRODUCTION}

Sepsis is a significant public health concern. ${ }^{1}$ Even with advanced medical knowledge and technology, sepsis is still the $2^{\text {nd }}$ leading cause of death among patients in non-coronary intensive care units (ICUs) ${ }^{2}$ and the $10^{\text {th }}$ leading cause of death overall in the United States. ${ }^{3}$

Statins are extensively used in medical practice as cholesterol-lowering agents and statin therapy has been shown to decrease coronary and cerebrovascular events and decrease mortality from coronary artery disease. ${ }^{4}$ In parallel, statins possess a number of pleiotropic effects that are thought to have a beneficial effect on the cascade of detrimental events that characterize the sepsis syndrome. In vitro, studies have shown that statins increase the physiologic concentrations of nitric oxide (NO) by increasing the expression of endothelial NO synthase and down-regulating inducible NO synthase thus reversing the endothelial dysfunction seen in sepsis ${ }^{5}$ Statins have also been shown to decrease production of proinflammatory cytokines such as tumor necrosis factor $\alpha$ (TNF- $\alpha$ ), interleukin-1 (IL-1), and IL-6 present during sepsis6 and interfere with the recognition of microbial products by immune cells thus depressing the inflammatory cascade. ${ }^{7}$ Furthermore, statins also demonstrate antioxidant and apoptotic properties that play a crucial role in blunting the effects of sepsis. ${ }^{4}$ While some studies ${ }^{8,9}$ demonstrated a mortality benefit in patients taking statins in sepsis, four studies ${ }^{10-13}$ showed no mortality benefit from statins and one ${ }^{14}$ reported an increased mortality in patients taking statins. Furthermore, even though many studies have been performed regarding genetic polymorphism influencing the clinical response to statins ${ }^{15}$, few results have been replicated in different population. The goal of our study is to evaluate the effect of statin-treatment on mortality in patients with sepsis in the Lebanese population.

\section{METHODS}

We conducted a retrospective study of patients who were hospitalized at two tertiary care hospitals in Beirut and admitted to ICU with a clinical diagnosis of sepsis based on international classification of disease (ICD-10) code from January 2008 through March 2012.

The clinical diagnosis of sepsis was confirmed according to the criteria proposed by the American College of Chest Physicians and the Society of Critical Care Medicine. ${ }^{16}$ Patients with age less than 18 years, pregnant women and not Lebanese patients were excluded from the study.

Selection of patients was done using the computerized patient files. These files were used in order to retrieve the necessary information for the study. The research support was a questionnaire completed for each patient. Clinical parameters including age, sex, underlying medical conditions, concurrent medications (antibiotics, corticosteroids and statins), isolates of pathogen, vital signs, and laboratory data at time of bacteremia were collected.

Patients who took a statin before the sepsis episode and continued to receive statin therapy during the hospital course were included in the statin group, while the control group consisted of patients having sepsis and not taking statin.

Nosocomial blood stream infections were defined as positive blood cultures yielding more than 48 hours after admission. The occurrence of septic shock during hospitalization was defined as persistent hypotension (a systolic BP of $<90 \mathrm{mmHg}$ or a reduction of $>40 \mathrm{mmHg}$ from baseline, in the absence of other causes for the fall in blood pressure) unresponsive to volume resuscitation. ${ }^{16}$

Overall mortality was assessed. Subgroup analyses for septic patients with different underlying diseases, different severity of sepsis and different treatment received were performed with regard to the effect of statins on the mortality of sepsis. The study was approved by the institutional review board (IRB) committee of the two hospitals.

\section{Statistical analysis}

The comparison of nominal variables between the 2 groups was evaluated using chi-square test and Fisher exact test, while Student test was used for normally distributed continuous variables. Data were presented as means and standard deviation (SD) or as numbers and percentages. In case of non-normal distribution or non-homogenous variances, the Mann-Whitney test was used to compare continuous variables between two groups. Log-rank test and Cox regression analysis were applied to identify predictors of mortality, using the proportional hazards assumption. Observed survival curves were calculated using the Kaplan-Meyer technique. For all statistical tests, a $p<0.05$ was considered statistically significant and $95 \% \mathrm{Cl}$ were calculated for some parameters, namely risk ratio, adjusted risk ratio and hazard ratio. Statistical analyses were performed using SPSS software version 17. 


\begin{tabular}{|c|c|c|c|c|}
\hline Characteristics & $\begin{array}{l}\text { All patients } \\
(n=351)\end{array}$ & $\begin{array}{c}\text { Statin group } \\
(n=106)\end{array}$ & $\begin{array}{c}\text { Control group } \\
(n=245)\end{array}$ & P.value \\
\hline Age (y) & $71.33 \pm 14.4$ & $71.96 \pm 12.56$ & $71.06 \pm 15.21$ & 0.56 \\
\hline Male sex (no [\%]) & $195(55.6 \%)$ & $64(60.4 \%)$ & $131(53.5 \%)$ & 0.232 \\
\hline $\begin{aligned} \text { Temperature } & \leq 36\left({ }^{\circ} \mathrm{C}\right) \\
& >38\left({ }^{\circ} \mathrm{C}\right)\end{aligned}$ & $51(14.5 \%)$ & $11(10.4 \%)$ & $40(16.3 \%)$ & 0.15 \\
\hline Heart rate $>90 / \mathrm{min}$ & $176(50.1 \%)$ & $51(48.1 \%)$ & $125(51.0 \%)$ & 0.62 \\
\hline $\mathrm{WBC}^{*} \geq 12000 / \mathrm{mm}^{3}$ & $279(79.5 \%)$ & $85(80.2 \%)$ & $194(79.2 \%)$ & 0.83 \\
\hline $\mathrm{WBC}^{*} \leq 4000 / \mathrm{mm}^{3}$ & $42(12.0 \%)$ & $12(11.3 \%)$ & $30(12.2 \%)$ & 0.81 \\
\hline WBC $^{*}>10 \%$ Bands & $20(5.7 \%)$ & $2(1.9 \%)$ & $18(7.3 \%)$ & 0.04 \\
\hline Respiratory rate $\geq 20 / \mathrm{min}$ & $213(60.7 \%)$ & $62(58.5 \%)$ & $151(61.6 \%)$ & 0.58 \\
\hline $\mathrm{Pco}^{* \star}<32 \mathrm{~mm} \overline{\mathrm{H} g}$ & $224(63.8 \%)$ & $68(64.2 \%)$ & $156(63.7 \%)$ & 0.93 \\
\hline Previous diagnosis & $\begin{array}{c}\text { All patients } \\
(\mathrm{n}=311)\end{array}$ & $\begin{array}{c}\text { Statin group } \\
(n=93)\end{array}$ & $\begin{array}{c}\text { Non statin group } \\
(n=218)\end{array}$ & P.Value \\
\hline $\begin{array}{c}\text { History of cardiovascular disease } \\
\text { - } \quad \text { Arterial hypertension } \\
\text { - Coronary artery disease } \\
\text { - Cerebrovascular disease } \\
\text { Cardiac failure }\end{array}$ & $\begin{array}{l}199(64 \%) \\
168(54 \%) \\
81(26 \%) \\
50(16.1 \%) \\
40(12.9 \%)\end{array}$ & $\begin{array}{l}74(79.6 \%) \\
62(66.7 \%) \\
39(41.9 \%) \\
24(25.8 \%) \\
15(16.1 \%)\end{array}$ & $\begin{array}{l}125(57.3 \%) \\
106(48.6 \%) \\
42(19.3 \%) \\
26(11.9 \%) \\
25(11.5 \%)\end{array}$ & $\begin{array}{l}0.0001 \\
0.003 \\
0.0001 \\
0.002 \\
0.261\end{array}$ \\
\hline History of diabetes & $114(36.7 \%)$ & $48(51.6 \%)$ & $66(30.3 \%)$ & 0.0001 \\
\hline History of chronic kidney diseases & $57(18.3 \%)$ & $23(24.7 \%)$ & $34(15.6 \%)$ & 0.06 \\
\hline History of cancer & $27(8.7 \%)$ & $6(6.5 \%)$ & $21(9.6 \%)$ & 0.362 \\
\hline History of dyslipidemia & $60(19.3 \%)$ & $58(62.4 \%)$ & $3(1.4 \%)$ & 0.0001 \\
\hline Others $^{* * *}$ & $152(48.9 \%)$ & $41(44.1 \%)$ & $111(50.9 \%)$ & 0.27 \\
\hline \multicolumn{5}{|c|}{ 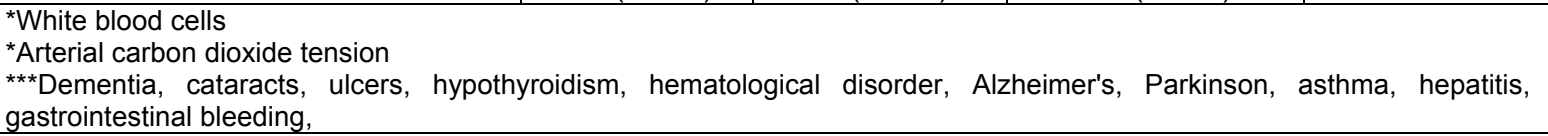 } \\
\hline
\end{tabular}

\section{RESULTS}

391 patients with sepsis as a clinical diagnosis were selected. 40 of them were excluded because of a non-Lebanese nationality or an age less than 18 and 351 patients were included in our study. Among these patients, 106 patients (30\%) were taking a statin therapy for dyslipidemia, and 245 (70\%) were not. Systemic inflammatory response syndrome (SIRS) criteria and other characteristics of all hospitalized patients with sepsis, statin group and control group are shown in Table 1 . The statin group had more cardiovascular disease $(p=0.0001)$, diabetes $(p=0.0001)$ and dyslipidemia $(p=0.0001)$ than the control group.

Among the statin group, rosuvastatin was the most commonly used (86 patients: $81.1 \%$, dose range: $10-20 \mathrm{mg} / \mathrm{d}$ ). The others included atorvastatin (30 patients: $18.3 \%$; dose range: $10-40 \mathrm{mg} / \mathrm{d}$ ), fluvastatin (9 patients: $8.5 \%$; dose: $80 \mathrm{mg} / \mathrm{d}$ ) and pravastatin (3 patients: $2.8 \%$; dose: $40 \mathrm{mg} / \mathrm{d}$ ).

The sources of infection were similar between groups except for urinary tract infection $(60.6 \%$ vs $42.4 \% ; p=0.017)$ and pulmonary tract infection accounted for half of the identifiable sources of bacteremia for all patients. Both groups had approximately similar proportions of Gram-positive bacteremia and Gram-negative bacteremia, but the statin group had presented more Escherichia coli $(p=0.05)$ and Candida species $(p=0.097)$ in their cultures than control group (Table 2).

The number of empirical antibiotic used showed that there was a significantly difference between the two groups $(p=0.03)$. The statin group had received more antibiotics like imipenem/cislatin, ciprofloxacin and amoxicillin than the control group (Table 3).

The mean serum level of CRP at the time of bacteremia was significantly lower in the statin group $(65.4 \mathrm{SD}=69.55$ vs $82.67 \mathrm{SD}=77.16 \mathrm{mg} / \mathrm{dl}$, $p=0,05)$ and the four fold serum level of CPK was significantly increased $(p=0.019)$. The duration of hospitalization were increased in statin group $(p=0.047)$ and the mortality was decreased $(p=0.0001)$ compared with the control group (Table $4)$.

Table 4 showed the different variables that were significantly associated with mortality by univariate

\begin{tabular}{|l|c|c|c|c|}
\hline \multicolumn{5}{|c|}{ Table 2. Types of infection in hospitalized patients with sepsis, statin group and control group } \\
\hline \multicolumn{1}{|c|}{ Etiology of blood stream infections } & $\begin{array}{c}\text { All patients } \\
\mathrm{n}(\%)(\mathrm{n}=299)\end{array}$ & $\begin{array}{c}\text { Statin group } \\
\mathrm{n}(\%)(\mathrm{n}=89)\end{array}$ & $\begin{array}{c}\text { Control group } \\
\mathrm{n}(\%)(\mathrm{n}=210)\end{array}$ & p.value \\
\hline Gram-positive bacteria & $150(50.2 \%)$ & $50(56.2 \%)$ & $100(47.6 \%)$ & 0.176 \\
\hline Staphylococcus spp & $124(41.5 \%)$ & $41(46.1 \%)$ & $83(39.5 \%)$ & 0.294 \\
\hline Streptococcus spp & $15(5 \%)$ & $7(7.9 \%)$ & $8(3.8 \%)$ & 0.121 \\
\hline Enterococcus spp & $38(12.7 \%)$ & $11(12.4 \%)$ & $27(12.9 \%)$ & 0.906 \\
\hline Corynebacteriae spp & $1(0.3 \%)$ & $1(0.5 \%)$ & $0(0 \%)$ & 1 \\
\hline Gram-negative bacteria & $227(75.9 \%)$ & $69(77.5 \%)$ & $158(75.2 \%)$ & 0.672 \\
\hline Escherichia coli & $119(39.8 \%)$ & $43(48.3 \%)$ & $76(36.2 \%)$ & 0.05 \\
\hline Acinetobacter spp & $113(37.8 \%)$ & $36(40.4 \%)$ & $77(36.7 \%)$ & 0.537 \\
\hline Pseudomonas spp & $74(24.7 \%)$ & $24(27 \%)$ & $50(23.8 \%)$ & 0.563 \\
\hline Proteus spp & $38(12.7 \%)$ & $14(15.7 \%)$ & $25(11.9 \%)$ & 0.369 \\
\hline Klebsiella spp & $59(19.7 \%)$ & $18(20.2 \%)$ & $41(19.5 \%)$ & 0.889 \\
\hline Candida spp & $113(37.8 \%)$ & $40(44.9 \%)$ & $73(36.2 \%)$ & 0.097 \\
\hline
\end{tabular}




\begin{tabular}{|c|c|c|c|c|}
\hline Antibiotics received & $\begin{array}{c}\text { All patients } \\
(\mathrm{n}=345)\end{array}$ & $\begin{array}{l}\text { Statin group } \\
(\mathrm{n}=102)\end{array}$ & $\begin{array}{c}\text { Control group } \\
(n=243)\end{array}$ & p.value \\
\hline Number of antibiotics & $4.52 \pm 2.43$ & $5.16 \pm 2.62$ & $4.25 \pm 2.3$ & 0.03 \\
\hline Imipenem/cislatin or Tienam® & $228(66.1 \%)$ & $77(75.5 \%)$ & $151(66.6 \%)$ & 0.017 \\
\hline Vancomycin & $181(52.5 \%)$ & $54(52.9 \%)$ & $127(52.7 \%)$ & 0.908 \\
\hline Amikacin & $143(41.4 \%)$ & $44(43.1 \%)$ & $99(44.7 \%)$ & 0.68 \\
\hline Métronidazole ou Flagy|® & $126(36.5 \%)$ & $39(38.5 \%)$ & $87(35.8 \%)$ & 0.668 \\
\hline Tazocin & $96(27.8 \%)$ & $31(30.4 \%)$ & $65(26.7 \%)$ & 0.491 \\
\hline Ciprofloxacin & $95(27.5 \%)$ & $39(38.2 \%)$ & $56(23 \%)$ & 0.004 \\
\hline Colimycin & $93(27 \%)$ & $30(31.4 \%)$ & $62(25.5 \%)$ & 0.351 \\
\hline Levofloxacin or Tavanic $₫$ & $69(20 \%)$ & $24(23.5 \%)$ & $45(18.5 \%)$ & 0.288 \\
\hline Moxifloxacin or Avalox® & $55(15.9 \%)$ & $21(20.6 \%)$ & $34(14 \%)$ & 0.127 \\
\hline Tigecyclin or Tigacy|® & $52(15.1 \%)$ & $16(15.7 \%)$ & $36(14.8 \%)$ & 0.836 \\
\hline Amoxicillin & $50(14.5 \%)$ & $21(20.6 \%)$ & $29(11.9 \%)$ & 0.037 \\
\hline Meropenem or Meronem ${ }^{\circledR}$ & $47(13.6 \%)$ & $12(11.8 \%)$ & $35(14.4 \%)$ & 0.514 \\
\hline Ceftriaxon or Triaxone ${ }^{\circledR}$ & $45(13 \%)$ & $41(40.2 \%)$ & $74(30.5 \%)$ & 0.08 \\
\hline Ceftazidim or Fortum $\otimes$ & $45(13 \%)$ & $12(11.8 \%)$ & $33(13.6 \%)$ & 0.648 \\
\hline Teicoplamin or Targocid $\AA$ & $43(12.5 \%)$ & $18(17.6 \%)$ & $25(10.3 \%)$ & 0.059 \\
\hline Other antibiotics* & $104(30.1 \%)$ & $38(37.3 \%)$ & $66(27.2 \%)$ & 0.062 \\
\hline
\end{tabular}

analysis : previous dyslipidemia, hypothermia, hyperthermia, bands $>10 \%$, treatment with vancomycin, tigacyl, tazocin, colymicin, candida, infection with Gram negative bacteria, acinetobacter, pseudomonas, statin treatment, corticosteroids treatment, septic shock (Table 5).

Multivariate logistic regression analysis was performed on the variables identified by univariate analysis and on those mentioned in the literature. Statin treatment was associated with decreased incidence of mortality $(\mathrm{p}=0.001$; adjusted risk ratio, 0.394 ; $95 \% \mathrm{Cl}: 0.225-0.690$ ), while a nosocomial infection with Acinetobacter, hypothermia, and septic shock were associated with a higher incidence of mortality (Table 6).

The overall survival among patients who took statins was better than patients without statin treatment $(p=0.0001) \quad$ (Figure 1). Hypothermia (hazard risk=1.999; 95\% Cl: 1.255-3,183; $p=0.004$ ) and a septic shock occurred during hospitalization (hazard risk=3.093; 95\% Cl: 2.044-4.681; $p=0.0001$ ) were significantly associated with mortality in a multiple Cox regression analysis. However, when statin was taken in account there was also statistically significant association statin treatment and mortality (hazard risk $=0.540 ; 95 \% \mathrm{Cl}$ : $0.302-$ 0.964; $p=0.037$ ).

\section{DISCUSSION}

In our study, the statin group had more previous cardiovascular disease particularly more arterial hypertension, coronary artery disease (CAD) and cerebrovascular disease $(p=0.003,0.0001$ and $0.002)$ and more diabetes $(p=0.0001)$. These results are compatible with the study by Martin et al. ${ }^{11}$, in which the statin group had more diabetes $(81.3 \%$ vs $35.1 \% ; p=0.003)$, and more stroke $(25 \%$ vs $2.7 \%$; $\mathrm{p}=0.025$ ) and with the study conducted by Thomsen et al 12 in which the statin group had more CAD $(33 \%$ vs $7 \%$ ), more diabetes ( $23 \%$ vs $10 \%)$. In addition, the statin group had more urinary tract infection $(p=0.017)$. This can be due to the fact that diabetes is one of the risk factor of urinary tract infection ${ }^{17}$, or it was predominant in the statin group. Ciprofloxacin and imipenem/cilastatin found to be more prescribed for this group. Ciprofloxacin has higher renal clearance and greater renal concentration, considered an optimal choice for the treatment of complicated urinary tract infections. ${ }^{18}$ Imipenem, combined with an inhibitor of its metabolism by renal tubular cells (cilastatin), has been used successfully to treat serious urinary tract infections.

The serum levels of CRP were significantly lower in the statin group than in the control group (65.4 $\mathrm{SD}=69.55$ vs $82.67 \mathrm{SD}=77.16 \mathrm{mg} / \mathrm{L}, \mathrm{p}=0.05$ ) at the time of sepsis. Statin treatment was associated with a significant $21 \%$ reduction in CRP. Statins reduce CRP levels significantly (13 to $50 \%$ ) according to several clinical trials. Possible explanations to this observation include that the baseline characteristics of the statin group were not as severely septic as those of the non-statin group and because lipids might attenuate the intensity of inflammatory

\begin{tabular}{|c|c|c|c|}
\hline & $\begin{array}{l}\text { Statin group } \\
\quad(n=106)\end{array}$ & $\begin{array}{c}\text { Control group } \\
(n=245)\end{array}$ & p.value \\
\hline Mortality & $42(39.6 \%)$ & $149(60.8 \%)$ & 0.0001 \\
\hline Duration of hospitalization & $25.24 \pm 26.43$ & $19.38 \pm 22.015$ & 0.047 \\
\hline CRP (mg/dl) & $65.4 \pm 69.55$ & $82.67 \pm 77.16$ & 0.05 \\
\hline \multirow[b]{2}{*}{$\begin{array}{l}1 \\
2 \\
3 \\
4 \\
5\end{array}$} & Statin group $(n=66)$ & Non statin $(n=194)$ & p.value \\
\hline & $\begin{array}{c}43(65.2 \%) \\
8(12.1 \%) \\
3(4.5 \%) \\
6(9.1 \%) \\
6(9.1 \%)\end{array}$ & $\begin{array}{c}147(75.8 \%) \\
16(8.2 \%) \\
8(4.1 \%) \\
4(2.1 \%) \\
19(9.8 \%)\end{array}$ & $\begin{array}{c}0.093 \\
0.348 \\
1 \\
0.019 \\
0.867\end{array}$ \\
\hline
\end{tabular}




\begin{tabular}{|c|c|c|}
\hline Variables & Risk ratio $(95 \% \mathrm{Cl})$ & p.value \\
\hline Previous dyslipidemia & $0.214[0.115 ; 0.40]$ & 0.0001 \\
\hline Hypothermia $\left(\mathrm{T}<36^{\circ} \mathrm{C}\right)$ & $2.506[1.301 ; 4.825]$ & 0.005 \\
\hline Hyperthermia(T>38॰C) & $0.531[0.317 ; 0.887]$ & 0.015 \\
\hline Vancomycin & $2.336[1.514 ; 3.604]$ & 0.000 \\
\hline Tigacyl & $2.059[1.094 ; 3.873]$ & 0.023 \\
\hline Tazocin & $1.864[1.143 ; 3.039]$ & 0.012 \\
\hline Colymicin & $1.969[1.198 ; 3.235]$ & 0.007 \\
\hline Candida & $1.655[1.026 ; 2.668]$ & 0.038 \\
\hline Gram-negative bacteria & $1.769[1.036 ; 3.019]$ & 0.035 \\
\hline Acinetobacter & $2.702[1.647 ; 4.431]$ & 0.0001 \\
\hline Pseudomonas & $1.993[1.147 ; 3.462]$ & 0.014 \\
\hline Statin treatment & $0.423[0.265 ; 0.674]$ & 0.0001 \\
\hline Corticosteroids treatment & $2.091[1.354 ; 3.228]$ & 0.001 \\
\hline Septic shock & $6.665[3047 ; 14.581]$ & 0.0001 \\
\hline
\end{tabular}

response ${ }^{20}$; thus, since lipid levels were significantly higher in the statin group, the CRP levels could have thus decreased because of the inflammationattenuating effect of these lipids.

Interestingly, statin therapy was associated with a lower mortality rate in the statin versus the control group. This result confirms the findings of a metaanalysis $^{20}$ that demonstrated a protective effect for statins in patients with sepsis and/or other infections compared to placebo for various infection-related outcomes. Of the 20 studies included in this metaanalysis, 15 studies demonstrated a mortality benefit in patients taking statins, with adjusted ORs ranging from 0.06 to 0.75 . The benefits of statins seen in this study are also supported by a number of animal studies. Ando et al. ${ }^{2 \uparrow}$ used a lipopolysaccharide (LPS)-induced sepsis murine model to show that pretreatment with cerivastatin significantly improved 7-day survival in septic mice, and furthermore, serum levels of TNF- $\alpha$ and IL-1 were reduced at 2 hours as were serum levels of $\mathrm{NO}$, nitrite, and nitrate at 8 hours. Yasuda et al. ${ }^{22}$ evaluated the effect of statins on polymicrobial sepsis using a cecal ligation and puncture model in mice and found that pretreatment with simvastatin significantly increased duration of survival from 28 to 105 hours and 3 -day survival from $26 \%$ to $73 \%$ compared to untreated mice. These animal models complement the human epidemiologic evidence and collectively suggest that statins increase survival in sepsis, have a positive effect and interfere with the signal cascade leading to the sepsis syndrome.

We could not exclude that increased atherosclerotic burden, as reflected in a higher incidence of CAD and myocardial infarctions in the statin group, had a significant impact that we could not determine at the present time. Currently, we do not have enough data to explain how sepsis, CAD, and antiinflammatory therapies interact with the therapies against atherosclerosis. Interestingly, there appeared to be a lower rate of mortality in patients without CAD than that in CAD patients. However, the study was underpowered to allow a clear answer to this group of patients with such a high mortality. There was a discernible trend of higher mortality related to hypothermia, septic shock and nosocomial infection due to Acinetobacter.

The four fold serum level of CPK was significantly increased among the patients who continued to receive statin $(9.1 \%$ vs $2.1 \% ; p=0.019)$. However, serious side effects of statins such as myopathy and rhabdomyolysis are rare in the general patient population; the incidence and severity of these adverse effects may not be the same in critically ill populations, particularly given the recent findings by Kruger et al. ${ }^{23}$ that demonstrated altered pharmacokinetics of statins in these patients. Administration of a modest dose atorvastatin (20 $\mathrm{mg}$ ) can result in marked elevations of plasma concentration in critically ill patients with sepsis. ${ }^{23}$ The increase of CPK observed in our population could be related to drug-drug interactions: statins are substrates of the CYP3A4, and many drug indicated in ICU are enzymatic inhibitors of this cytochrome, such as antifungals (itraconazole, ketaconazole, voriconazole (strong inhibitors) and fluconazole) used for Candida treatment in our statin group.

\section{Survival Functions}

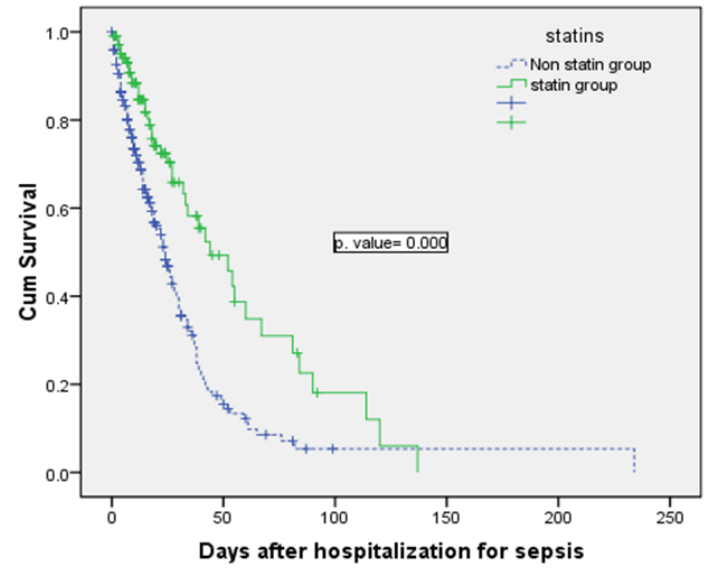

Figure 1. Kaplan-Meier curves showing the percentage of patients surviving in the statin group (solid line) and the control group (Dashed line).

\begin{tabular}{|l|c|c|}
\hline \multicolumn{1}{|c|}{ Table 6. Predictors of mortality among hospitalized patients with sepsis by multivariate analysis } \\
\hline \multicolumn{1}{|c|}{ Variables } & Adjusted risk ratio $(95 \% \mathrm{Cl})$ & p.value \\
\hline Hypothermia & $2.599[1.177 ; 5.738]$ & 0.018 \\
\hline Infection with Acinetobacter & $3.278[1.902 ; 5.648]$ & 0.0001 \\
\hline Statin treatment & $0.394[0.225 ; 0.690]$ & 0.001 \\
\hline Septic shock & $6.714[2.660 ; 16.945]$ & 0.0001 \\
\hline
\end{tabular}


Statin doses might also have impact on sepsis. And till now, only 2 studies (Fernandez et al. ${ }^{14}$ and Tseng et al. ${ }^{24}$ ) defined the dose of the statin given, and therefore, it is impossible to conclude from the current literature the adequate exposure to statins required to achieve a clinically significant result. Moreover, genetic and environmental factors may not only influence the development and progression of diseases but also the response to medication. The magnitude of response to treatment, even with the same dose of the same statin, may vary from $10 \%$ to $50 \%{ }^{25}$ A number of genetic polymorphisms have been evaluated in several clinical trials and single nucleotide polymorphisms (SNPs) have been examined in some 30 different genes. ${ }^{26}$ The results of our study may reflect that in Lebanese septic population, and statins prescribed at the doses for hypercholesterolemia reduce the mortality related to sepsis; however, we cannot refute the possibility of underlying genetic response to statins that may contribute to the differential results in patients.

There is abundant evidence supporting the effect of statins against inflammatory responses, yet there are still uncertainties with regard to how important race or ethnicity is in determining statins' protective effect against sepsis. Although, the benefits of statins are largely assumed to be a class effect; however, whether the pleiotropic effects of statins are similar across the subclass remains to be determined. ${ }^{27}$ Whether supratherapeutic plasma levels of statins in critically ill patients translates to an increased toxicity and requires a dose or formulation adjustment in these patients remains unclear. Further evaluations of safety are necessary before statin therapy can be implemented in this patient population. Recently, a liposomal form of pravastatin has been developed to inhibit tumor growth by targeting cancer-related inflammation. ${ }^{28}$
This form can be indicated in sepsis to reduce the mortality due to the sepsis.

There are many limitations of this retrospective study. First, exposure duration was variable between patients who received statin, since we did not have any information about the duration of statin therapy before the hospitalization. Second, the retrospective design of study limits our choice of variables. Third, the comparisons between the two groups was confounded by several baseline differences, including the severity of sepsis, the underlying burdens, making results difficult to interpret, but the multivariable statistical analysis was performed to reduce potential confounding factors. The significant association of certain antibiotics received during hospitalization to the observed mortality in the univariate model was probably due to confounding by indication. Finally, since our study was observational, a randomized controlled trial is suggested to confirm our findings in the Lebanese population.

\section{CONCLUSIONS}

Statins are extensively used in medical practice as cholesterol-lowering agents. At usual doses for dyslipidemia, statin treatment was associated with decreased mean serum of CRP at the time of septicemia, decreased incidence of mortality related to sepsis, and improved survival in the Lebanese septic population. Randomized clinical trials must be realized to give conclusive results about the beneficial effect of statins in sepsis.

\section{CONFLICT OF INTEREST}

None declared

\section{References}

1. Vincent JL, Sakr Y, Sprung CL, Ranieri VM, Reinhart K, Gerlach H, Moreno R, Carlet J, Le Gall JR, Payen D; Sepsis Occurrence in Acutely III Patients Investigators. Sepsis in European intensive care units: results of the SOAP study. Crit Care Med. 2006;34(2):344-353.

2. Kwak B, Mulhaupt $F$, Myit $S$, Mach F. Statins as a newly recognized type of immunomodulator. Nat Med. 2000;6(12):1399-1402.

3. Fehr T, Kahlert C, Fierz W, Joller-Jemelka HI, Riesen WF, Rickli H, Wüthrich RP, Ammann P. Statin-induced immunomodulatory effects on human T cells in vivo. Atherosclerosis. 2004;175(1):83-90.

4. Merx M, Weber C. Statins in the intensive care unit. Curr Opin Crit Care. 2006;12(4):309-314.

5. McGown C, Brookes Z. Beneficial effects of statins on the microcirculation during sepsis: the role of nitric oxide. $\mathrm{Br} \mathrm{J}$ Anaesth. 2007;98(2):163-175.

6. Zhang J, Cheng X, Liao YH, Lu B, Yang Y, Li B, Ge H, Wang M, Liu Y, Guo Z, Zhang L. Simvastatin regulates myocardial cytokine expression and improves ventricular remodeling in rats after acute myocardial infarction. Cardiovasc Drugs Ther. 2005;19(1):13-21.

7. Weitz-Schmidt G, Welzenbach K, Brinkmann V, Kamata T, Kallen J, Bruns C, Cottens S, Takada Y, Hommel U. Statins selectively inhibit leukocyte function antigen-1 by binding to a novel regulatory integrin site. Nat Med. 2001;7(6):687692.

8. Frost FJ, Petersen H, Tollestrup K, Skipper B. Influenza and COPD mortality protection as pleiotropic, dose-dependent effects of statins. Chest. 2007;131(4):1006-1012.

9. Hackam DG, Mamdani M, Li P, Redelmeier DA. Statins and sepsis in patients with cardiovascular disease: a population-based cohort analysis. Lancet. 2006;367(9508):413-418.

10. Majumdar SR, McAlister FA, Eurich DT, Padwal RS, Marrie TJ. Statins and outcomes in patients admitted to hospital with community acquired pneumonia: population based prospective cohort study. BMJ. 2006;333(7576):999.

11. Martin CP, Talbert RL, Burgess DS, Peters JI.. Effectiveness of statins in reducing the rate of severe sepsis: a retrospective evaluation. Pharmacotherapy. 2007;27(1):20-26. 
12. Thomsen RW, Hundborg HH, Johnsen SP, Pedersen L, Sørensen HT, Schønheyder HC, Lervang HH. Statin use and mortality within 180 days after bacteremia: a population-based cohort study. Crit Care Med. 2006;34(4):1080-1086.

13. Yang KC, Chien JY, Tseng WK, Hsueh PR, Yu CJ, Wu CC. Statins do not improve short term survival in an oriental population with sepsis. Am J Emerg Med. 2007;25(5):494-501.

14. Fernandez R, De Pedro VJ, Artigas A. Statin therapy prior to ICU admission: protection against infection or a severity marker? Intensive Care Med. 2006;32(1):160-164.

15. Bray PF, Cannon CP, Goldschmidt-Clermont P, Moyé LA, Pfeffer MA, Sacks FM, Braunwald E. The platelet PI(A2) and angiotensin-converting enzyme (ACE) $D$ allele polymorphisms and the risk of recurrent events after acute myocardial infarction. Am J Cardiol. 2001;88(4):347-352.

16. American College of Chest Physicians: Society of Critical Care Medicine Consensus Conference: definitions for sepsis and organ failure and guidelines for the use of innovative therapies in sepsis. Crit Care Med. 1992;20(6):864-874.

17. Ribera MC, Pascual R, Orozco D, Pérez Barba C, Pedrera V, Gil V. Incidence and risk factors associated with urinary tract infection in diabetic patients with and without asymptomatic bacteriuria. Eur J Clin Microbiol Infect Dis. 2006;25(6):389-393.

18. Hooper D. Quinolones. In: Mandell GL, Bennett JE, Dolin R. Mandell, Douglas, Bennett's. Principles and practice of infectious diseases. 5th ed. Philadelphia: Churchill Livingstone; 2000:404-423.

19. Cox CE, Corrado ML. Safety and efficacy of imipenem/cilastatin in treatment of complicated urinary tract infections. Am J Med. 1985;78(6A):92-94

20. Iribarren C, Jacobs DR Jr, Sidney S, Claxton AJ, Feingold KR. Cohort study of serum total cholesterol and in-hospital incidence of infectious diseases. Epidemiol Infect. 1998;121(2):335-347.

21. Ando H, Takamura T, Ota T, Nagai Y, Kobayashi K. Cerivastatin improves survival of mice with lipopolysaccharideinduced sepsis. J Pharmacol Exp Ther. 2000;294(3):1043-1046.

22. Yasuda H, Yuen P, Hu X, Zhou H, Star R. Simvastatin improves sepsis-induced mortality and acute kidney injury via renal vascular effects. Kidney Int. 2006;69(9):1535-1542.

23. Kruger $P$, Freir N, Venkatesh B, Robertson T, Roberts M, Jones M. A preliminary study of atorvastatin plasma concentrations in critically ill patients with sepsis. Intensive Care Med. 2009;35(4):717-721. doi: 10.1007/s00134-0081358-3.

24. Tseng MY, Hutchinson PJ, Czosnyka M, Richards H, Pickard JD, Kirkpatrick PJ. Effects of acute pravastatin treatment on intensity of rescue therapy, length of inpatient stay, and 6-month outcome in patients after aneurysmal subarachnoid hemorrhage. Stroke. 2007;38(5):1545-1550.

25. Jones P. Comparing HMG-CoA reductase inhibitors. Clin Cardiol. 2003;26(1 Suppl 1):I15-I20.

26. Kajinami K, Akao H, Polisecki E, Schaefer EJ. Pharmacogenomics of statin responsiveness. Am J Cardiol. 2005;96(9A):65K-70K;

27. Wang C, Liu P, Liao J. Pleiotropic effects of statin therapy: molecular mechanisms and clinical results. Trends Mol Med. 2008;14(1):37-44.

28. Coimbra M, Banciu M, Fens MH, de Smet L, Cabaj M, Metselaar JM, Storm G, Schiffelers RM. Liposomal pravastatin inhibits tumor growth by targeting cancer-related inflammation. J Control Release. 2010;148(3):303-310. doi: 10.1016/j.jconrel.2010.09.011. 